\title{
Seksisme sebagai moderator hubungan sense of community dan kinerja mahasiswa organisatoris
}

\author{
Andi Hakiki ${ }^{1}$ dan M. Fath Mashuri ${ }^{2}$
}

\begin{abstract}
The performance of student organizations is a crucial variable in maintaining their existence and achieving their organizational goals. One of the important factors that influence this is the degree of sense of community of the members of the organization. Sexism as a gender prejudice is considered to have the potential to influence aspects of the sense of community and organizational performance. This study aims to examine sexism as a moderator on the relationship between sense of community and organizational performance. This study uses a quantitative method and determines the subject using a random sampling technique to the members of student organizations with a total of 223 subjects. The measuring instrument used is Sense of Community version 2, The Ambivalent of Sexism Inventory, and an Organizational Performance Scale. Data analysis used the method of moderated regression analysis. The results showed that there was a significant relationship between sense of community and organizational performance, and sexism as a moderator variable had an insignificant value on the relationship between sense of community and organizational performance.
\end{abstract}

\section{Keywords}

Organizational performance, sense of community, sexism, university student

\section{Pendahuluan}

Kinerja organisasi memiliki peran krusial guna terus mengembangkan dan mempertahankan agar organisasi tersebut tetap berjalan. Menurut Mulyadi (2007) kinerja organisasi adalah keberhasilan personel, tim, atau organisasi dalam menjalankan sasaran strategis yang ditetapkan dengan perilaku-perilaku yang diharapkan dari organisasi. Bernardin \& Russel (2010) berpendapat bahwa kinerja merupakan kombinasi antara kemampuan dan sifat (ability and traits), usaha (effort), serta dukungan (support) yang diukur melalui hasil kerja yang telah dicapai seseorang. Gibson et al. (2000) mengartikan kinerja adalah hasil kerja yang terkait dengan tujuan organisasi seperti kualitas, efisiensi, dan kriteria keefektifan lain yang dicapai selama periode tertentu. Hal ini menjadikan kinerja dari anggota memberikan kontribusi terhadap pencapaian dari tujuan organisasi. Kinerja menggambarkan perasaan senang individu maupun kelompok yang mendalam terhadap kepuasan terhadap pekerjaan, kerja sama, serta lingkungan yang ikut serta mendorong anggota untuk bekerja lebih baik dan produktif.

Namun dalam organisasi, mahasiswa masih sering kali terjadi stagnasi dalam mencapai tujuannya. Terdapat fenomena mahasiswa mendadak tidak aktif atau hanya sebatas menjalankan kewajiban tanpa adanya ghiroh dalam pengembangan organisasi. Masalah-masalah tersebut dapat terjadi karena kurangnya motivasi maupun semangat yang ada pada anggota organisasi. Hal ini terjadi karena anggota dari organisasi kurang merasa nyaman, tidak peduli, tidak adanya kepercayaan, atau tidak adanya ikatan emosional antar anggota yang berarti anggotaanggota tersebut kurang memiliki sense of community (Dalton et al., 2007). Penelitian yang dilakukan AsensioMartínez et al. (2017) menunjukkan bahwa rendahnya sense of community anggota terhadap kelompok mendorong munculnya kejenuhan terhadap kelompok yang mengakibatkan anggota tidak memberikan kontribusi optimal yang berpengaruh terhadap keberlangsungan kelompok itu sendiri.

Sense of community merupakan perasaan anggota yang memiliki arti bagi anggota lain dan kelompoknya, serta adanya keyakinan bersama terhadap kebutuhan dalam diri akan terpenuhi melalui komitmen yang terjalin antar anggota (McMillan \& Chavis, 1986). Penelitian mengenai sense of community terhadap kinerja sendiri sudah banyak dilakukan oleh para peneliti sebelumnya. Nowell \& Boyd (2014) berpendapat bahwa sense of community merupakan konstruksi yang unik dikarenakan memiliki kemampuan untuk memprediksi kesejahteraan dari anggota sebuah

\footnotetext{
1,2Universitas Muhammadiyah Malang, Indonesia

Korespondensi:

Andi Hakiki, Fakultas Psikologi Universitas Muhammadiyah Malang

Email: andihakiki14@gmail.com
} 
komunitas serta intensitas keterlibatan terhadap hasil kinerja. Individu dengan sense of community yang tinggi dapat berpengaruh pada meningkatnya prestasi, interaktivitas, serta retensi dari individu Haar (2018). Hal tersebut membuat sense of community merupakan variabel yang penting bagi anggota dari sebuah organisasi demi terwujudnya cita-cita organisasi yang didukung dengan kinerja optimal dari anggota-anggotanya. Lampinen et al. (2017) menjelaskan bahwa faktor penguat bagi sense of community adalah perasaan saling memiliki, interaksi terbuka terkait masalah yang ada, rasa saling percaya, serta kebermaknaan pekerjaan. Beberapa hal tersebut bergerak linear dengan kualitas layanan yang diberikan oleh organisasi. Maryam (2017) mencoba untuk melihat gambaran sense of community pada karyawan bagian administrasi yang ternyata didapati hasil bahwa dari keempat dimensi mengenai sense of community, dimensi mengenai shared emotional connection merupakan urutan tertinggi dari dimensi-dimensi yang ada.

Berdasarkan penelitian-penelitian yang sudah dijabarkan di atas dapat diambil suatu garis besar bahwa perasaan saling memiliki dan rasa keterikatan antar anggota untuk saling berbagi dalam hubungan sosial berperan penting pada terbentuknya sense of community yang berhubungan dengan meningkatnya kinerja dalam komunitas maupun organisasi. Bisa disebutkan bahwa prasangka buruk maupun diskriminasi yang terjadi dalam organisasi dapat mempengaruhi kinerja organisasi dikarenakan sense of community yang kurang baik. Hal ini dapat berkaitan dengan interaksi antar-gender yang mengindikasikan adanya bentuk kesenjangan gender baik itu dalam konteks komunikasi verbal maupun nonverbal, serta distribusi informasi maupun kebijakan. Kondisi tersebut disebut dengan seksisme. Pada masyarakat Indonesia perilaku seksisme masih sering terjadi baik di lingkungan keluarga, pergaulan, olahraga, maupun organisasi, yang bahkan dilakukan oleh beberapa oknum di dalam pemerintahannya (Primastika, 2019; Setiawan, 2020).

Doob (2013) berpendapat seksisme merupakan suatu bentuk prasangka atau diskriminasi terhadap kelompok lain yang memiliki perbedaan gender atau jenis kelamin. Hal ini pula dapat merujuk pada keseluruhan sistem diferensial terhadap seks individu, sifat-sifat misoginis (kebencian terhadap wanita), maupun misandri (kebencian terhadap laki-laki). Macionis (2009) menjelaskan bahwa seksisme merupakan keyakinan bahwa salah satu gender lebih baik dari gender yang lain. Secara umum sexism mendukung sistem patriarki yang menganggap bahwa laki-laki memiliki kemampuan atau derajat yang lebih tinggi dibandingkan dengan perempuan, karena itu mereka (laki-laki) harus memiliki kuasa terhadapnya. Tindakan seksisme bisa saja terjadi karena adanya pengaruh stereotip terhadap peran gender serta keyakinan bahwa jenis kelamin tertentu memiliki posisi yang lebih tinggi dibandingkan yang lainnya (Johnson \& Shiffrar, 2013).
Organisasi mahasiswa yang memiliki anggota beragam macam budaya serta gender yang berbeda tentu memiliki beberapa kendala dalam pelaksanaannya. Sense of community maupun kinerja organisasi membutuhkan perasaan saling percaya baik kepercayaan yang memiliki arti antar anggota maupun kepercayaan anggota dalam mewujudkan cita-cita organisasi. Weber \& Higginbotham (1997) menemukan mayoritas anggota dengan ras maupun budaya yang berbeda-beda mendapatkan perlakuan seksis dalam organisasinya. Kepercayaan yang terjadi didasarkan seksisme berpotensi pada pelecehan bahkan perkosaan, moderasi seksisme terhadap kepercayaan yang kuat menjadikan korban menjadi subjek yang disalahkan, sedangkan jika gender sama-sama memiliki seksisme yang tinggi mereka cenderung menyepelekan pelecehan yang terjadi di lingkungannya (Yamawaki et al., 2007).

Dalam dinamika kinerja organisasi, prasangka salah satu gender lebih baik dibandingkan gender yang lain, dalam penelitiannya ditemukan seksisme sebagai moderator dalam penilaian yang berlebihan terhadap pemimpin perempuan (Wood, 2000). Selain itu, perempuan yang bekerja di sebuah organisasi yang diketuai oleh lakilaki melaporkan mengalami lebih banyak diskriminasi gender, dibandingkan dengan rekan-rekan mereka yang diketuai oleh perempuan (Konrad et al., 2010). Pemimpin yang didominasi oleh laki-laki cenderung membentuk sebuah sistem yang menghargai dan mempromosikan individu yang memiliki kesamaan dengan mereka, hal tersebut cenderung menyebabkan diskriminasi terhadap perempuan (Davison \& Burke, 2000; Roth, 2012). Dengan demikian, ketidaksetaraan gender dalam kepemimpinan mempengaruhi pengalaman perempuan diorganisasi dan mereka berkemungkinan menghadapi diskriminasi.

Berdasarkan data-data yang sudah dipaparkan, seksisme berpotensi menjadi moderator yang dapat mempengaruhi hubungan antara sense of community dengan kinerja organisasi (Dardenne et al., 2007). Hal itu dikarenakan seksisme sendiri merupakan suatu bentuk prasangka maupun diskriminasi antar gender yang tidak hanya pada perseorangan namun hal ini dapat terjadi pada lingkungan sosial atau kelompok gender itu sendiri.

Sakina \& Asiah (2017) pada penelitiannya menyimpulkan bahwa substansi bias gender tidak mungkin berubah menjadi adil gender, bila tidak adanya kesadaran dari pemerintah dan masyarakat yang masih merawat konstruksi sosial yang tidak adil gender. I Gusti Ayu Bintang Darmawati Puspayoga sebagai Menteri Pemberdayaan Perempuan dan Perlindungan Anak (PPPA) di Kantor Kementerian Agama saat menghadiri hari ulang tahun Parisadha Buddha Niciren Syosyu Indonesia (NSI) ke 55 di Jakarta menekankan akan pentingnya kesetaraan gender dalam berbagai sektor (Wildansyah, 2019). PPPA sendiri memiliki target yang ingin dicapai dalam meningkatkan derajat perempuan di Indonesia melalui pemberdayaan perempuan dalam bidang pendidikan, ekonomi, serta kekerasan terhadap anak dan perempuan. 
Pada tahun 2008 jumlah kekerasan terhadap perempuan di Indonesia sebanyak 54.425 sedangkan pada tahun 2019 sebanyak 431.471 kasus (Konrad et al., 2010). Dalam rentang waktu 12 tahun, kekerasan terhadap perempuan mengalami kenaikan sebanyak $792 \%$ atau hampir 8 kali lipat. Komnas perempuan sendiri menyatakan bahwa data tersebut masih merupakan fenomena gunung es. Hasil Survei Pengalaman Hidup Perempuan Nasional (SPHPN) tahun 2016 menyatakan bahwa 1 dari 3 perempuan berusia 15-64 tahun pernah mengalami kekerasan fisik dan/atau seksual dalam hidupnya (Badan Pusat Statistik, 2017).

Zuhra (2019) berpendapat bahwa tidak ada lembaga yang memiliki data akurat terkait jumlah kekerasan seksual yang terjadi di kampus yang tersebar di Indonesia, informasi-informasi yang tersebar muncul saat kasus menjadi sorotan media, blog pribadi, menyebar secara sporadis, dan dengan kerahasiaan yang rapat. Konrad et al. (2010) mencatat kekerasan yang terjadi dalam komunitas sebanyak 1200 korban dan 303 pelaku adalah seorang pelajar. Weiss (2010) dalam penelitiannya mendapatkan bahwa dari seluruh korban kekerasan seksual yang melaporkan ke penegak hukum hanya sekitar 30\% perempuan dan $15 \%$ laki-laki.

Dari data-data yang sudah dipaparkan, peneliti ingin mendalami kasus terkait seksisme pada anggota dalam organisasi mahasiswa. Apakah terdapat ambivalen terhadap sense of community dan kinerja organisasinya. Dalam penelitian ini seksisme akan berperan sebagai variabel moderator diantara sense of community dan kinerja organisasi. Seperti yang sudah dijelaskan bahwa seksisme sebagai prasangka memiliki peluang untuk mempengaruhi aspek-aspek dalam sense of community maupun kinerja organisasi. seksisme lebih banyak dialami oleh perempuan dibandingkan laki-laki, yang meliputi kekerasan verbal maupun fisik pada kelompok pelajar (Bucchianeri et al., 2013). Sehingga penelitian ini bersifat urgent dalam menganalisa serta menjadi referensi dalam membuat kebijakan-kebijakan organisasi terhadap perilaku seksisme dari anggota organisasi mahasiswa. Mengingat belum ada penelitian sebelumnya yang melakukan usaha serupa, peneliti berharap penelitian ini memiliki manfaat sebagai informasi maupun referensi dalam kajian ilmu psikologi sosial.

Peneliti sendiri menyadari adanya beberapa kendala dalam memulai penelitian ini: Pertama seksisme sendiri bukan hanya kegiatan yang kontroversial, namun juga menjadi problematis karena banyak orang yang enggan untuk menceritakan pengalaman atau kegiatan tertentu sebagai bentuk seksis. Kedua, dikarenakan seksisme hanya berupa prasangka yang belum tentu semua anggota dalam organisasi mahasiswa berperilaku demikian.

\section{Kinerja Organisasi}

Wibowo (2012) menjelaskan bahwa kinerja berasal dari pengertian performance. Kinerja atau performance sendiri merupakan visualisasi dari tingkat pencapaian pelaksanaan suatu program kegiatan dalam merealisasikan tujuan, cita-cita, ataupun visi dan misi dari orgnisasi melalui perencanaan strategis (Moeheriono, 2012). Kinerja dibagi menjadi 3 level yaitu: kinerja individu, kinerja proses, dan kinerja organisasi (Sudarmanto, 2009).

Kinerja organisasi merupakan keberhasilan personel, team, atau organisasi dalam menjalankan sasaran strategis yang ditetapkan dengan perilaku-perilaku yang diharapkan dari organisasi Mulyadi (2007). Kinerja organisasi merupakan gambaran mengenai tingkat pencapaian pelaksanaan tugas pada suatu organisasi, sebagai bentuk upaya mewujudkan tujuan, sasaran, misi dan visi dari organisasi tersebut (Tangkilasan, 2005) . Sedangkan Keban (2008) menjelaskan bahwa kinerja organisasi menunjukan seberapa jauh suatu organisasi merealisasikan tujuannya.

Kinerja adalah bagaimana individu dapat melakukan fungsi dan berperilaku sesuai dengan tugas yang telah diberikan kepadanya (Miner, 1990). individu dalam organisasi memiliki peran dan cara mereka berperilaku dalam melaksanakan tugas organisasi baik organisasi pemerintahan, privat, maupun sosial untuk mencapai tujuan melalui sarana dalam bentuk yang digerakan oleh sekelompok orang yang berperan aktif (Fahrurazi et al., 2014).

Dapat disimpulkan bahwa kinerja organisasi merupakan gambaran keberhasilan personil, team, atau organisasi melalui perilaku-perilaku dalam merealisasikan atau mewujudkan tujuan, sasaran, misi dan visi dari organisasi. Melalui kinerja organisasi diharapkan seluruh elemen dalam organisasi dapat saling membantu satu dengan yang lain berdasarkan asas yang ada pada organisasi.

Dalam pelaksanaan kegiatan guna mencapai suatu keberhasilan, terdapat faktor-faktor dalam organisasi yang dapat mempengaruhi keberhasilan tersebut. Faktor-faktor yang dimaksud dapat mempengaruhi kinerja organisasi menurut pandangan para ahli, yaitu: Pertama, stuktur organisasi sebagai hubungan internal yang berkaitan dengan fungsi menjalankan aktivitas organisasi. Kedua, kebijakan pengelola yang berupa visi dan misi dari organisasi. Ketiga, sumber daya manusia yang berfungsi dalam kualitas baik dalam bekerja maupun berkarya secara optimal. Keempat, sistem informasi manajemen yang berfungsi sebagai database anggota organisasi baik dalam evaluasi maupun meningkatkan performa kinerja organisasi. Kelima, sarana dan prasarana, yang berguna dalam mendukung kinerja maupun aktivitas dari organisasi (Sudarmanto, 2009).

Tangkilasan (2005) mengidentifikasi faktor-faktor yang memiliki pengaruh langsung dalam kinerja organisasi, yaitu: Pertama, teknologi yang meliputi peralatan kerja yang digunakan untuk menghasilkan produk atau jasa yang dihasilkan oleh organisasi. Kedua, kualitas input yang digunakan dalam organisasi: a. Kualitas lingkungan fisik baik dalam kebersihan maupun tata ruang; b. Budaya organisasi selaku pola kerja serta pola tingkah laku yang ada di dalam lingkungan organisasi; c. Kepemimpinan guna mengendalikan anggota organisasi dalam mencapai 
tujuan organisasi yang sesuai dengan standar yang telah ditetapkan. Ketiga, pengelolaan sumber daya manusia.

Sudarmanto (2009) menjelaskan bahwa ada empat aspek yang berperan sebagai tolak ukur dalam menilai kinerja organisasi, yaitu: (1) Kualitas dari tingkat error atau kesalahan maupun kecermatan dari organisasi, (2) Kuantitas dari jumlah pekerjaan yang dapat diselesaikan, (3) Penggunaan waktu dalam bekerja yang meliputi tingkat ketidakhadiran atau keterlambatan maupun waktu kerja efektif dan jam kerja yang hilang, (4) Kerjasama dengan orang lain dalam bekerja.

\section{Sense of Community}

Dalton et al. (2007) menjelaskan sense of community merupakan perasaan anggota yang memiliki arti bagi anggota lain dan kelompoknya, serta adanya keyakinan bersama terhadap kebutuhan dalam diri akan terpenuhi melalui komitmen yang terjalin antar anggota. Sarason menjabarkan hal yang serupa mengenai sense of community yaitu berupa persepsi akan adanya kesamaan dengan orang lain, adanya rasa saling ketergantungan, hasrat dalam mempertahankan interdependensi dengan melakukan sesuatu untuk orang lain, serta adanya perasaan bahwa seseorang menjadi bagian dari sebuah kelompok (Patria, 2012). Sedangkan Aguilar (2008) berpendapat bahwa sense of community merupakan kondisi saling mengenal satu sama lain, memiliki rasa saling percaya, dan berkeinginan untuk bekerja sama dikarenakan pertemuan yang intens diantara mereka.

Berdasarkan pemaparan sebelumnya, maka dapat disimpulkan sense of community merupakan perasaan anggota mengenai adanya kesamaan dengan orang lain, memiliki rasa saling bergantung satu sama lain, serta memiliki hasrat dalam mempertahankan interdependensi untuk melakukan sesuatu dengan untuk orang lain dengan kondisi pertemuan yang intens sehingga tercipta rasa saling percaya, mengenal satu dengan yang lain, dan berkeinginan untuk bekerja sama.

Anggota dalam sebuah kelompok akan lebih baik jika memiliki sense of community, hal ini agar menjaga kekokohan serta keberlangsungan kelompok itu sendiri. Adanya sikap apatis dari anggota kelompok dapat menjadi faktor penghambat kualitas interaksi antar anggota, sehingga hal tersebut dapat berdampak pada keberlanjutan sebuah kelompok atau komunitas (Maryam, 2017).

Dalam menumbuhkan sense of community, McMillan \& Chavis (1986) berpendapat bahwa terdapat 4 aspek yang seharusnya ada dalam komunitas, yaitu: (1) Membership (keanggotaan) merupakan perasaan saling memiliki atau ikatan yang ada karena menjadi bagian dalam komunitas, (2) Influence (pengaruh) yang diartikan sebagai perasaan yang mempengaruhi atau dipengaruhi oleh komunitas atau individu yang ada di dalamnya, (3) Integration and fulfillment of need (reinforcement of needs) adalah perasaan akan terpenuhinya kebutuhan dari anggota yang berasal dari sumber-sumber dalam kelompoknya, (4) emotional connection (perasaan saling terhubung) yaitu adanya perasaan anggota bahwa kejadian-kejadian penting di dalam komunitas dilakukan secara bersama-sama pada waktu dan tempat yang sama, atau komitmen antara anggota dalam kelompok untuk saling berbagi pada sejarah, pengalaman, maupun waktu dengan anggota yang lain. Keempat aspek tersebut saling berinteraksi dan saling memberikan kontribusi terhadap munculnya rasa memiliki individu atau sense of community pada komunitas.

McMillan \& Chavis (1986) menjelaskan bahwa terdapat 5 hal yang dapat meningkatkan sense of community dari anggota dalam kelompok, yaitu: (1) Boundaries (keterikatan), dari setiap anggota kelompok (bahasa, pakaian, dan ritual) yang membedakan antara anggota dari kelompok dan yang tidak. (2) Emotional safety, ditandai dengan rasa aman maupun keterbukaan antara satu dengan yang lain antar para anggota dalam mengetahui perasaan satu sama lain. (3) Sense of belonging and identification, merupakan harapan atau kepercayaan seseorang yang merasa bahwa dirinya diterima dalam sebuah kelompok. (4) Personal investment, adalah usaha yang dilakukan oleh anggota untuk menjadi anggota kelompok. (5) $A$ common symbol system (simbol umum) yang berfungsi untuk menciptakan serta memelihara rasa keterkaitan antar anggota kelompok.

\section{Seksisme}

Doob (2013) berpendapat seksisme merupakan suatu bentuk prasangka atau diskriminasi terhadap kelompok lain yang memiliki perbedaan gender atau jenis kelamin. Hal ini pula dapat merujuk pada keseluruhan sistem diferensial terhadap seks individu, sifat-sifat misoginis (kebencian terhadap wanita) maupun misandri (kebencian terhadap laki-laki). Macionis (2009) menjelaskan bahwa seksisme merupakan keyakinan bahwa salah satu gender lebih baik dari gender yang lain. Secara umum seksisme mendukung sistem patriarki yang dimana mereka menganggap bahwa laki-laki memiliki kemampuan atau derajat yang lebih tinggi dibandingkan dengan perempuan, karena itu mereka (laki-laki) harus memiliki kuasa terhadapnya. Sakall1Uğurlu et al. (2007) mendefinisikan seksisme sebagai suatu sikap atau keyakinan bahwa salah satu jenis kelamin lebih unggul, lebih berharga, dan lebih kompeten daripada jenis kelamin yang lain. Johnson \& Shiffrar (2013) menjelaskan tindakan seksisme bisa saja terjadi karena adanya pengaruh stereotip terhadap peran gender serta keyakinan bahwa jenis kelamin tertentu memiliki posisi yang lebih tinggi dibandingkan yang lainnya.

Maka dapat disimpulkan bahwa seksisme merupakan bentuk prasangka maupun diskriminasi antar gender baik laki-laki terhadap perempuan maupun sebaliknya yang beranggapan bahwa gender mereka lebih baik dibandingkan yang lain, seksisme pula tidak hanya terjadi pada perseorangan namun hal ini dapat terjadi pada lingkungan sosial atau kelompok gender itu sendiri. Sebagian besar perilaku seksisme dilakukan kepada 
perempuan. Hal ini diperkuat dengan sistem patriarki yang dimana laki-laki seharusnya dapat lebih baik dibandingkan perempuan, hal tersebut berkembang melalui tempat kerja, sistem politik, bahkan kehidupan beragama (Macionis, 2009). Glick \& Fiske (2011) mendefinisikan seksisme ke dalam 2 komponen berbeda, berupa permusuhan dengan stereotip negatif dan peran gender tradisional yang berupa pembatasan serta penempatan peran perempuan dengan status dan kekuasaan yang lebih sedikit dibandingkan lakilaki.

Faktor-faktor pembentuk perilaku seksisme menurut Allport (Nuqul, 2004) yang menjadi sumber kefanatikan sebagai faktor awal prasangka, yaitu: (1) doktrin dari wahyu, (2) penetapan diri untuk bergabung dengan kelompok, (3) teokrasi. Sedangkan Nuqul (2004) berpendapat faktor-faktor penyebab prasangka adalah: (1) karakteristik otoriter, (2) rendahnya harga diri, (3) orientasi dominasi sosial, (4) religiusitas, (5) anjuran agama untuk saling mengasihi.

Glick \& Fiske (2011) berpendapat dalam seksisme sendiri terdapat ambivalen yang merupakan sebuah konsep teori dalam memperluas pemahaman terkait seksisme. Ambivalen dalam seksisme yaitu: (1) Benevolent sexism (seksisme kebajikan) yang berupa sikap subjektif yang positif terhadap perlindungan, idealisasi, dan kasih sayang terhadap perempuan. Namun secara tidak sadar benevolent sexism menunjukan bahwa kedudukan perempuan lebih rendah dibandingkan laki-laki, (2). Hostile sexism yang didefinisikan sebagai sikap yang tidak memiliki dominasi, degradasi, permusuhan, dan kesetaraan. Hostile sexism lebih mendekati pada seksisme tradisional yang berupa tindakan ofensif, lelucon seksis, dan pelecehan (Glick \& Fiske, 2011; Nuqul, 2004).

Glick \& Fiske (2011) dalam skala The Ambivalent Sexism Inventory (ASI) membagi aitem pada hostile sexism dan benevolent sexism, serta membagi benevolent sexism menjadi 3 aspek lain, yaitu: protactive paternalism merupakan cara seseorang dalam berhubungan dengan orang lain yang dilandasi oleh hubungan mendominasi serta hubungan kasih sayang atau perlindungan, gender differentiation merupakan perbedaan fisik pada jenis kelamin yang digunakan sebagai landasan dasar diferensiasi sosial, dan terakhir heterosexsual intimacy merupakan merupakan rasa ingin memiliki terhadap hubungan atau keintiman dengan gender yang berbeda.

\section{Moderasi seksisme pada Sense of Community dengan Kinerja Organisasi}

Sense of community merupakan faktor kuat yang mempengaruhi munculnya partisipasi anggota terhadap program kelompok yang merupakan salah satu dari aspek kinerja organisasi (Falatehan, 2017). Dengan adanya sense of community yang kuat, maka menimbulkan dorongan kuat pada anggota kelompok untuk merealisasikan atau mewujudkan tujuan dari organisasi. Prayoga \& Herdiyanto (2014) dalam penelitiannya mendapatkan hasil bahwa terdapat korelasi positif dan signifikan antara sense of community dan kinerja, hal ini mengartikan bahwa jika terjadi peningkatan pada variabel sense of community maka akan terjadi peningkatan pula pada variabel kinerja dan begitu sebaliknya.

Menurut McMillan \& Chavis (1986), sense of community dapat terbentuk dari perasaan-perasaan yang dimiliki anggota komunitas seperti perasaan nyaman dan senang dalam berbagi cerita antar anggota dikarenakan kesamaan yang dimiliki, serta ikatan kuat yang merupakan hasil dari interaksi yang dilakukan antar anggota, semakin tinggi intensitas interaksi maka akan terbentuk keakraban diantara anggota. Sehingga kualitas input dalam organisasi akan meningkat serta sumber daya manusia menjadi lebih kokoh dalam melaksanakan tugas-tugas yang ada pada organisasi, hal tersebut merupakan faktor-faktor yang berpengaruh langsung terhadap kinerja organisasi (Tangkilasan (2005).

Dalam organisasi mahasiswa yang memiliki anggota beragam macam budaya serta gender yang berbeda tentu memiliki beberapa kendala dalam pelaksanaannya. Sense of community maupun kinerja organisasi membutuhkan perasaan saling percaya baik kepercayaan yang memiliki arti antar anggota maupun kepercayaan anggota dalam mewujudkan cita-cita organisasi. Weber \& Higginbotham (1997) mendapatkan mayoritas anggota dengan ras maupun budaya yang berbeda-beda mendapatkan perlakuan seksis dalam organisasinya. Salah satu yang dapat mempengaruhi adalah seksisme, dikarenakan seksisme sendiri merupakan suatu bentuk prasangka maupun diskriminasi antar gender yang tidak hanya pada perseorangan namun hal ini dapat terjadi pada lingkungan sosial atau kelompok gender itu sendiri. Dardenne et al. (2007) dalam penelitiannya menjelaskan bahwa sexism dapat berpengaruh buruk pada kinerja dari perempuan. Shelton $e t$ al. (2006) menjelaskan bahwa individu yang gagal dalam menghadapi diskriminasi dan stereotip (seksisme) yang dialaminya dapat mengurangi kapasitas memori kerja yang berakibat pada berkurangnya kinerja di masa depan.

Organisasi yang memiliki sense of community yang tinggi akan bersama-sama mewujudkan cita-cita maupun tujuan dari organisasi jika anggota dari organisasi tersebut tidak memiliki prasangka maupun diskriminasi terhadap anggota dengan gender berbeda. Artinya anggota yang seksis mampu mempengaruhi hubungan antar sense of community dengan kinerja organisasi. Hal yang berbeda akan terjadi jika anggota memiliki kepribadian seksisme yang tinggi dan apabila sense of community tinggi namun anggota tidak melakukan tugas dari organisasi. Dengan maksud seksisme yang tinggi akan mempengaruhi hubungan antara sense of community dengan kinerja organisasi. Model hubungan sense of community dengan kinerja organisasi dimoderasi oleh seksisme dapat dilihat pada Gambar 1. 


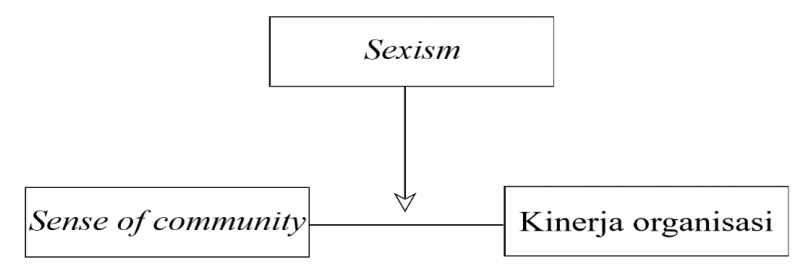

Gambar 1. Model hubungan sense of community dengan kinerja organisasi dimoderasi oleh seksisme

\section{Hipotesa 1}

Ada hubungan positif antara sense of community dengan kinerja organisasi.

\section{Hipotesa 2}

Seksisme menjadi moderator hubungan sense of community dengan kinerja organisasi.

\section{Metode}

Penelitian ini menggunakan pendekatan kuantitatif dengan desain korelasional. Penelitian korelasional merupakan suatu penelitian untuk mengetahui hubungan dan tingkat hubungan antara dua variabel atau lebih tanpa mempengaruhi atau manipulasi variabel dan merefleksikan hubungan variabel dalam koefisien korelasi (Sukardi, 2004). Penelitian dilaksanakan guna mengkaji penelitian sebelumnya. Penelitian mencoba untuk menyajikan bagaimana variabel moderator $(\mathrm{Z})$ berperan pada hubungan variabel bebas $(\mathrm{X})$ dan variabel terikat $(\mathrm{Y})$.

\section{Subjek Penelitian}

Subjek dalam penelitian yakni anggota organisasi mahasiswa dengan teknik random sampling. Teknik random sampling merupakan teknik mengambil sampel dengan cara memberikan skala pada sampel yang memenuhi kriteria sebagai sampel dari populasi tertentu. Kriteria yang dimaksud dalam penelitian ini adalah (a) Mahasiswa aktif, (b) Anggota dari organisasi mahasiswa, dan (c) Berusia 1723 tahun.

Jumlah populasi sebanyak 798, penentuan jumlah sampel menggunakan Nomogram Harry King dengan tingkat kesalahan (level errors) sebesar 5\%, maka jumlah sampel sekitar $28 \%$ dari populasi atau sebanyak 223. Data demografi subjek penelitian dapat dilihat pada Tabel 1.

\section{Variabel dan Instrumen Penelitian}

Pada penelitian ini terdapat 3 variabel yaitu variabel bebas (X) sense of community, variabel terikat (Y) kinerja organisasi, dan variabel moderator $(\mathrm{Z})$ yaitu seksisme.

Instrumen sense of community diukur dengan sense of community index version two (SCI-2) hasil pengembangan Chavis, Lee, dan Acosta dari sense of community index (SCI) yang dibuat berdasarkan teori dari McMillan dan
Tabel 1. Demografi Subjek Penelitian

\begin{tabular}{lrr}
\hline Kategori & Frekuensi & $\%$ \\
\hline Usia & & \\
18 tahun & 8 & 3.6 \\
19 tahun & 51 & 22.9 \\
20 tahun & 58 & 26.0 \\
21 tahun & 64 & 28.7 \\
22 tahun & 29 & 13.0 \\
23 tahun & 13 & 5.8 \\
Jenis Kelamin & & \\
Laki - laki & 82 & 36.8 \\
Perempuan & 141 & 63.2 \\
Posisi dalam organisasi & & \\
Anggota & 141 & 63.2 \\
Pimpinan & 82 & 36.8 \\
\hline
\end{tabular}

Chavis (Chavis et al., 2008). Terdapat 4 aspek dalam sense of community yang terdiri dari membership (keanggotaan), influence (pengaruh), reinforcement of needs (penguatan dan pemenuhan kebutuhan), dan a shared emotional connection (perasaan saling terhubung). Reliabilitas dari SCI-2 sebesar 0.89 dengan nilai daya beda item 0.457 - 0.818, skala yang digunakan untuk mengukur sense of community merupakan skala likert yang terdiri dari 5 kategori pilihan mulai dari sangat setuju sampai sangat tidak setuju.

Kinerja organisasi mahasiswa diukur dengan skala berdasarkan teori John B. Miner. Definisi kinerja organisasi yang dikemukakan Miner (1990) adalah bagaimana fungsi dan perilaku individu terhadap tugas yang telah dibebankan kepadanya, bagaimana perilaku dan peran mereka dalam organisasi sesuai dengan tujuan serta melaksanakan tugasnya dengan baik. Kinerja organisasi memiliki 4 aspek yang berperan sebagai tolak ukur dalam menilai kinerja organisasi yaitu: kualitas, kuantitas, penggunaan waktu, dan kerjasama. Skala pengukuran ini memiliki nilai reliabilitas sebesar 0.9 dengan nilai daya beda item 0.389 - 0.774. Skala yang digunakan untuk mengukur kinerja organisasi merupakan skala likert yang terdiri dari 5 kategori pilihan mulai dari sangat setuju sampai sangat tidak setuju.

The Ambivalen Sexism Inventory (ASI) merupakan skala yang dibuat oleh Peter Glick dan Susan T. Fiske untuk mengukur ambivalen seksisme. Seksisme biasanya dikonseptualisasikan sebagai cerminan dari permusuhan terhadap perempuan, yang mengabaikan aspek signifikan terhadap perasaan positif subyektif dari perempuan yang berjalan beriringan dengan antipati seksis (Glick \& Fiske, 2011). Dalam ASI terdapat 2 dimensi yang terdiri dari hostile sexism dan benevolent sexism, pada benevolent sexism dibagi kembali menjadi 3 aspek lain, yaitu: protactive paternalism, gender differentiation, dan heterosexsual intimacy. ASI memiliki reliabilitas sebesar 0.79 dengan nilai daya beda item $0.310-0.727$. Skala yang digunakan untuk mengukur seksisme merupakan skala 
likert yang terdiri dari 5 kategori pilihan mulai dari sangat setuju sampai sangat tidak setuju.

\section{Prosedur dan Analisis Data}

Prosedur pada penelitian terdapat tiga tahapan, tahapan pertama merupakan tahap perencanaan, tahap perencanaan sendiri meliputi perancangan proposal penelitian, mempelajari variabel penelitian dari sumber-sumber penelitian terdahulu, serta perancangan dan menentukan alat ukur yang akan digunakan dalam penelitian. Perancangan alat ukur sendiri berupa menerjemahkan alat ukur SCI-2 (Sense of Community version 2) dan ASI (The Ambivalent of Sexism Inventory) ke dalam bahasa Indonesia, serta menyusun skala kinerja organisasi berdasarkan teori John B. Miner.

Tahap kedua merupakan tahap pelaksanaan, alat ukur berupa skala yang akan digunakan dilakukan uji coba guna mengetahui validitas dan reliabilitas dari alat ukur (SCI-2, skala kinerja organisasi, dan ASI) yang akan digunakan, uji coba meliputi judgement expert dan try out pada mahasiswa yang mengikuti organisasi mahasiswa sebanyak 63 subjek. Pada hasil try out yang dilakukan didapatkan bahwa reliabilitas dari ASI sebesar 0.79 dan item valid berjumlah 10 dari 22 item yang terdapat dalam ASI, pada SCI-2 reliabilitas sebesar 0.89 dan item valid sebanyak 21 dari 24 item, sedangkan untuk skala kinerja organisasi memiliki nilai reliabilitas 0.9 dengan item valid sebanyak 18 dari 20 item. Setelah diketahui validitas dan reliabilitas dari alat ukur sudah memenuhi standar dilanjutkan dengan penyebaran skala pada subjek sesuai kriteria sebanyak 223 subjek.

Tahap ketiga atau terakhir yaitu analisa data serta penulisan laporan penelitian. Teknik analisa data yang digunakan dalam penelitian ini yaitu Moderated Regression Analysis (MRA). Teknik MRA sendiri bertujuan untuk melihat pengaruh sense of community terhadap kinerja organisasi yang dimoderasi oleh variabel seksisme. Apabila seksisme berhubungan dengan besarnya pengaruh dalam sense of community terhadap kinerja organisasi, maka dapat diambil kesimpulan bahwa seksisme memoderasi pengaruh sense of community terhadap kinerja organisasi (Hayes, 2013).

\section{Hasil}

Subjek dalam penelitian merupakan mahasiswa yang mengikuti atau terdaftar dalam organisasi mahasiswa. Hasil penelitian yang dilakukan bisa dilihat pada Tabel 2. Hasil penelitian menunjukan nilai Mean (M) dan standar deviasi (SD) pada masing-masing variabel. Variabel sense of community $(\mathrm{X})$ memiliki nilai rata-rata $(\mathrm{M}=47.97$; $\mathrm{SD}=12.02)$, variabel seksisme $(\mathrm{Z})$ memiliki nilai ratarata $(M=24.65 ; S D=6.34)$, dan variabel kinerja organisasi (Y) memiliki nilai rata-rata $(\mathrm{M}=40.89 ; \mathrm{SD}=10.45)$. Hasil uji korelasi antar variabel menunjukan bahwa masingmasing variabel memiliki hubungan positif. Variabel sense of community berhubungan signifikan positif dengan seksisme dengan besaran nilai $(\mathrm{r}=0.12, p<0.01)$, variabel
Tabel 2. Deskripsi Statistik

\begin{tabular}{llllll}
\hline Variabel & $M$ & SD & 1 & 2 & 3 \\
\hline 1. Sense of Community & 47.97 & 12.02 & 1 & & \\
2. Sexism & 24.65 & 6.34 & $0.12^{* *}$ & 1 & \\
3. Kinerja Organisasi & 40.89 & 10.45 & $0.72^{* *}$ & $0.26^{* *} 1$ \\
\hline
\end{tabular}

Tabel 3. Hasil Analisa Data

\begin{tabular}{lllll}
\hline Variabel & $\beta$ & $t$ & $p$ & $R^{2}$ \\
\hline Model 1 & & & & \\
$\quad$ Constant & 4.50 & 1.79 & 0,07 & \\
$\quad$ Sense of Community & 0.61 & 15.47 & 0.00 & \\
$\quad$ seksisme & 0.29 & 3.86 & 0.00 & \\
$\quad$ Model 2 & & & & \\
$\quad$ Constant & 10.11 & 1.44 & 0.14 & \\
$\quad$ Sense of Community & 0.49 & 3.26 & 0.00 & \\
$\quad$ seksisme & 0.08 & 0.33 & 0.74 & \\
$\quad$ Interaksi & 0.01 & 0.86 & 0.39 & 0.55 \\
\hline
\end{tabular}

seksisme dengan kinerja organisasi $(\mathrm{r}=0.72, p<0.01)$, dan variabel sense of community dengan kinerja organisasi dengan besaran nilai $(\mathrm{r}=0.26, p<0.01)$.

Variabel sense of community memiliki nilai koefisien sebesar $\beta=0.486$ dengan nilai signifikansi $p=0.00(p<$ $0.05)$. Variabel seksisme memiliki nilai koefisien $\beta=0.083$ dengan nilai signifikansi sebesar $p=0.74(p>0.05)$. Variabel interaksi menunjukan nilai koefisien sebesar $\beta$ $=0.005$ dengan nilai signifikansi sebesar $p=0.39(p>$ $0.05)$. Variabel interaksi yang merupakan perkalian antara variabel sense of community dengan seksisme memiliki tingkat tidak signifikan yang berarti variabel seksisme bukanlah sebuah variabel moderating.

Pada Tabel 3 diketahui bahwa nilai Adjusted $\mathrm{R}^{2}$ sebesar 0.550 hal tersebut dapat diartikan bahwa variabel kinerja organisasi (Y) dapat dipengaruhi oleh variabel sense of community $(\mathrm{X})$ dan variabel seksisme (Z) sebesar 55\%, sehingga $45 \%$ dipengaruhi oleh faktor-faktor lain.

\section{Pengaruh sense of community terhadap kinerja organisasi}

Hasil yang didapatkan dengan menggunakan analisa MRA menunjukan bahwa hipotesa 1 diterima, dikarenakan terdapat pengaruh positif dan signifikan antara sense of community dengan kinerja organisasi $(\beta=0.486$; $\mathrm{p}=0.00)$. Hal tersebut dapat diartikan semakin tinggi sense of community maka semakin tinggi pula kinerja organisasinya. Sebaliknya semakin rendah sense of community maka semakin rendah kinerja organisasi

\section{Pengaruh sense of community terhadap kinerja organisasi}

Hasil yang didapatkan dari analisis MRA terhadap variabel pengaruh sense of community terhadap kinerja organisasi dengan seksisme sebagai variabel moderator memiliki nilai koefisien sebesar $\beta=0.005(\mathrm{p}=0.39>\mathrm{p}=0.05)$ 
sehingga hipotesis kedua ditolak. Hal ini dapat diartikan bahwa seksisme bukanlah variabel moderating, sehingga variabel seksisme tidak mempengaruhi hubungan sense of community terhadap kinerja organisasi.

\section{Diskusi}

Penelitian ini dilakukan guna meneliti pengaruh sense of community terhadap kinerja organisasi dengan seksisme sebagai variabel moderator. Penelitian dilakukan kepada 223 mahasiswa yang mengikuti organisasi mahasiswa di dalam maupun di luar kampus. Hasil penelitian menyatakan bahwa sense of community memiliki pengaruh positif pada kinerja organisasi, hal ini menunjukkan bahwa semakin tinggi sense of community maka kinerja organisasi juga akan menjadi tinggi. Pernyataan tersebut didapatkan dari nilai hasil uji korelasi terhadap variabel sense of community terhadap kinerja organisasi, sehingga hipotesis 1 diterima. Sense of community merupakan keyakinan bersama anggota bahwa kebutuhan dalam dirinya akan terpenuhi dengan interaksi positif antar anggota (McMillan \& Chavis (1986). Interaksi positif antar anggota dapat terjadi dengan pelaksanaan program dalam organisasi baik program dalam tatanan internal maupun eksternal, hal tersebut dapat meningkatkan kinerja dari sebuah organisasi dikarenakan tingkat pencapaian dalam pelaksanaan suatu program guna merealisasikan tujuan dari organisasi (Moeheriono, 2012). Kemudian Miner (1990) menjelaskan bahwa kinerja adalah bagaimana anggota dapat melakukan fungsi dan peranan mereka sesuai dengan tugas yang diberikan kepadanya. Proses mencapai tujuan organisasi, organisasi digerakkan oleh sekelompok individu yang berperan aktif dalam upaya menjalankan fungsi dan tugas mereka ( Arifin (2015)).

Anggota yang memiliki sense of community yang tinggi memiliki rasa keterikatan terhadap anggota dan organisasinya, adanya keyakinan bersama antar anggota melalui komitmen terhadap kebutuhan dirinya akan terpenuhi dalam organisasi termanifestasikan pada rasa saling percaya, mengenal satu sama lain, serta berkeinginan untuk bekerja sama untuk kepentingan bersama (Aguilar, 2008). Hasil ini sejalan dengan penelitian sebelumnya, seperti yang disampaikan Lampinen et al. (2017) menjelaskan bahwa faktor penguat bagi sense of community adalah perasaan saling memiliki, interaksi terbuka terkait masalah yang ada, rasa saling percaya, serta kebermaknaan pekerjaan, hal-hal tersebut bergerak linear dengan kualitas layanan yang diberikan oleh organisasi. Kemudian Ramos et al. (2017) yang meneliti tingkat sense of community pada Hispanic immigrants yang berada di Amerika Serikat menemukan bahwa adanya korelasi positif yang signifikan terhadap partisipasi dari subjek penelitiannya, bentuk partisipasi yang ada meliputi memberikan sumbangan kepada organisasi dalam komunitas, berdiskusi mengenai isu-isu yang berkembang, menjadi sukarelawan, dan berpartisipasi dalam keorganisasiannya. Oleh sebab itu saat anggota memiliki rasa keterikatan, interaksi, dan rasa saling percaya maka hal tersebut mampu membuat produktifitas dalam organisasi terbentuk dan dapat terus maju dalam mencapai tujuan dari organisasi.

Selanjutnya hasil penelitian didapati bahwa sense of community mempengaruhi kinerja organisasi dan seksisme bukanlah variabel moderating. Hal berikut dapat terjadi dikarenakan seksisme hanya bertindak sebagai variabel independen yang secara positif memperkuat kinerja organisasi, namun tidak mempengaruhi hubungan antara sense of community dengan kinerja organisasi. Berdasarkan teknik MRA interaksi antara sense of community dan seksisme secara signifikan tidak meningkatkan $\mathrm{R}^{2}$ serta nilai koefisien dari interaksi sense of community dan seksisme adalah tidak signifikan (Hayes, 2013). Grubbs et al. (2014) berpendapat bahwa hasil tersebut dapat terjadi dikarenakan faktor gender pada mahasiswa yang didapatkan akan berbeda berdasarkan gender. Oleh karena itu seksisme tidak mempengaruhi tinggi rendahnya suatu hubungan antara sense of community dengan kinerja organisasi, sehingga hipotesis 2 ditolak. Namun sebagai variabel independen, seksisme memberikan pengaruh positif terhadap kinerja organisasi. Hal ini dapat terjadi dikarenakan sexism memiliki ambivalen yang berupa benevolent sexism yang merupakan sikap terhadap perlindungan, idealisasi serta kasih sayang terhadap perempuan, dan hostile sexism yang didefinisikan sebagai sikap tidak memiliki dominasi, degradasi, permusuhan, dan kesetaraan (Glick \& Fiske (2011). Individu dengan tingkat seksisme tinggi memiliki toleransi terhadap perlakuan seksis yang diterimanya, hal tersebut membuat sexism hanya berperan terhadap sikap perlindungan dan lelucon semata (Russell \& Trigg, 2004). Sehingga, hal tersebut menjadi salah satu faktor terbentuknya perasaan nyaman dan senang dalam berbagi cerita antar anggota yang memiliki kesamaan serta ikatan yang kuat.

Hurst \& Beesley (2013) menemukan hasil yang berbeda bahwa sexism merupakan faktor yang mempengaruhi psychological distress terhadap hubungan mahasiswi di perguruan tinggi, terlebih pengaruh seksisme bertanggung jawab terhadap self silencing pada subjek penelitian, hal tersebut dapat mempengaruhi aspek-aspek kinerja organisasi seperti kualitas dari tingkat error atau kesalahan maupun kecermatan dari organisasi serta kerjasama dengan orang lain dalam bekerja. Sehingga, berakibat terhadap lemahnya kinerja organisasi dikarenakan tidak adanya aspek-aspek dalam meningkatkan kinerja organisasi. Cheng et al. (2020) mengungkapkan dalam penelitiannya bahwa benevolent sexism pada organisasi memiliki pengaruh signifikan terhadap gangguan karir pada wanita sedangkan untuk pria hal ini berpengaruh terhadap konflik kerja yang dilampiaskan pada keluarganya, artinya semakin tinggi perilaku seksisme maka kinerja dari organisasi akan semakin rendah. 
Adanya perilaku seksisme secara langsung maupun tidak langsung memberikan dampak terhadap komunitas di dalam lingkungannya. Ambivalent sexism (hostile/benevolent sexism) memberikan dampak signifikan terhadap reaksi emosi marah dan reaksi terganggu pada kedua gender, hal tersebut dapat terjadi pada gender yang merasakannya secara langsung maupun tidak (Bosson et al., 2010).

Berdasarkan penjelasan sebelumnya maka seksisme dapat memperkuat pengaruh sense of community terhadap kinerja organisasi. Namun, hal tersebut dapat terjadi jika individu berada pada lingkungan dengan perilaku seksisme, sehingga terdapat kesepakatan dan toleransi terhadap sikap seksisme yang diberikan maupun diterima. Keterbatasan pada penelitian ini adalah alat ukur ambivalent sexism inventory yang asli lebih dari setengah itemnya gugur dan peneliti tidak merubah ataupun memodifikasi instrumen dikarenakan item valid masih mencakup keseluruhan faktor pada ASI serta menjaga keaslian alat ukur yang digunakan.

\section{Kesimpulan}

Penelitian yang telah dilakukan dengan Moderated Regression Analysis (MRA) menunjukan terdapat hubungan signifikan dari sense of community terhadap kinerja organisasi. serta sexism sebagai variabel moderator memiliki nilai tidak signifikan terhadap hubungan sense of community dengan kinerja organisasi sehingga seksisme bukanlah variabel moderating.

Implikasi dari hasil penelitian ini mengarah pada pengambilan kebijakan dalam organisasi mahasiswa terhadap seksisme yang ada. Kebijakan harus memperhatikan ambivalent sexism terhadap anggota dari organisasi sehingga dapat terbentuknya sense of community yang akan berpengaruh terhadap kinerja dari organisasi mahasiswa, keputusan-keputusan tersebut dapat berupa kebijakan terhadap anggota dalam organisasi, struktur, maupun program kerja atau agenda yang dilaksanakan sesuai visi misi atau tujuan yang telah disepakati dari organisasi mahasiswa. Bagi peneliti selanjutnya diharapkan menguji kembali instrumen yang digunakan peneliti. Selain itu, diharapkan menimbang kembali variabel-variabel lain di luar dari variabel dalam penelitian ini, serta melihat variabel yang mempengaruhi kinerja organisasi seperti trust issue, peran gender, dan komitmen.

\section{Referensi}

Aguilar, A. C. J. (2008). Track 2 diplomacy and the asean peace: the role of experts in the development towards a security community-a case study on ASEAN-ISIS. Master thesis. University of Oslo, Norway.

Arifin, M. (2015). Hubungan iklin organisasi dengan kinerja anggota DPRD Kabupaten Pamekasan [Undergraduate thesis, Universitas Islam Negeri Mulana Malik Ibrahim]. http://etheses.uin-malang.ac.id/1489/
Asensio-Martínez, Á., Leiter, M. P., Gascón, S., Gumuchian, S., Masluk, B., Herrera-Mercadal, P., \& García-Campayo, J. (2017). Value congruence, control, sense of community and demands as determinants of burnout syndrome among hospitality workers. International Journal of Occupational Safety and Ergonomics, 25(2), 287-295. https://doi.org/10. 1080/10803548.2017.1367558

Badan Pusat Statistik. (2017). Prevalensi kekerasan terhadap perempuan di indonesia, hasil SPHPN 2016. Indonesia: Badan Pusat Statistik.

Benda, J. (1999). Pengkhianatan kaum cendekiawan. (Terj. Winarsih P. A.). Jakarta: Gramedia Pustaka Utama.

Bernardin. H. J. \& Russel J. E. A. (2010). Human resources management. New York: McGraw-Hill.

Bosson, J. K., Pinel, E. C., \& Vandello, J. A. (2010). The emotional impact of ambivalent sexism: Forecasts versus real experiences. Sex Roles, 62(7), 520-531. https://doi.org/10. 1007/s11199-009-9664-y

Bucchianeri, M. M., Eisenberg, M. E., \& Neumark-Sztainer, D. (2013). Weightism, racism, classism, and sexism: Shared forms of harassment in adolescents. Journal of Adolescent Health, 53(1), 47-53. https://doi.org/10.1016/j.jadohealth. 2013.01.006

Chavis, D. M., Lee, K. S., \& Acosta, J. D. (2008). The sense of community (SCI) revised: The reliability and validity of the SCI-2. The 2nd International Community Psychology Conference (1-3). Lisboa, Portugal: Community Science.

Cheng, P., Shen, W., \& Kim, K. Y. (2020). Personal endorsement of ambivalent sexism and career success: An investigation of differential mechanisms. Journal of Business and Psychology, 35(6), 783-798. https://doi.org/10.1007/s10869019-09652-9

Dalton, J. H., Elias, M. J., \& Wandersman, A. (2007). Community psychology: Linking individuals and communities (2nd edition). Belmont, CA: Thomson Wadsworth.

Dardenne, B., Dumont, M., \& Bollier, T. (2007). Insidious dangers of benevolent sexism: Consequences for women's performance. Journal of Personality and Social Psychology, 93(5), 764-779. https://doi.org/10.1037/0022-3514.93.5.764

Davison, H. K., \& Burke, M. J. (2000). Sex discrimination in simulated employment contexts: A meta-analytic investigation. Journal of Vocational Behavior, 56(2), 225-248. https: //doi.org/10.1006/jvbe.1999.1711

Doob, C. B. (2013). Social inequality and social stratification in US society. Upper Saddle River, NJ: Pearson Education.

Fahrurazi, R., Ghalib, S., \& Arifin, H. (2014). Pengaruh komunikasi dan budaya organisasi terhadap kinerja karyawan PT. Bank Pembangunan daerah Kalimantan Selatan wilayah Banjarmasin. Jurnal Bisnis dan Pembangunan, 1(1), 37-46. http://dx.doi.org/10.20527/jbp.v1i1.791

Falatehan, S. F. (2017). Pendekatan Psikologi Komunitas Dalam Memprediksi Peranan Rasa Memiliki Komunitas Terhadap Munculnya Partisipasi Masyarakat. MANASA, 6(1), 66-90. http://ojs.atmajaya.ac.id/index.php/manasa-old/ article/view/628 
Gibson, J. L., Ivancevich, J. M., \& Donnelly, J. H. (2000). Organizations: Behaviour, structure, and process. Boston: McGraw-Hill.

Glick, P., \& Fiske, S. T. (2011). Ambivalent sexism revisited. Psychology of women quarterly, 35(3), 530-535. https://doi. org/10.1177/0361684311414832

Grubbs, J. B., Exline, J. J., \& Twenge, J. M. (2014). Psychological entitlement and ambivalent sexism: Understanding the role of entitlement in predicting two forms of sexism. Sex Roles, 70(5-6), 209-220. https://doi.org/10.1007/s11199-014-03601

Haar, M. (2018). Increasing sense of community in higher education nutrition courses using technology. Journal of Nutrition Education and Behavior, 50(1), 96-99. https://doi. org/10.1016/j.jneb.2017.04.015

Hasibuan, M. S. P. (2011). Manajemen sumber daya manusia. Jakarta: Bumi Aksara.

Hayes, A. F. (2013). Methodology in the social sciences introduction to mediation, moderation, and conditional process analysis: A regression based approach. New York: Guilford Press.

Hurst, R. J., \& Beesley, D. (2013). Perceived sexism, selfsilencing, and psychological distress in college women. Sex Roles, 68(5-6), 311-320. https://doi.org/10.1007/s11199012-0253-0

Johnson, K. L., \& Shiffrar, M. (2013). People watching: Social perceptual, and neurophysiological studies of body perception. New York: Oxford University Press.

Keban, Y. T. (2008). Enam dimensi strategis administrasi publik: Konsep, teori, dan isu. Yogyakarta: Gava Media.

Komisi Nasional Anti Kekerasan Terhadap Perempuan. (2020). Catatan tahunan 2019: kekerasan meningkat: kebijakan penghapusan kekerasan seksual untuk membangun ruang aman bagi perempuan dan anak perempuan. Jakarta, Indonesia: KOMNAS Perempuan.

Konrad, A. M., Cannings, K., \& Goldberg, C. B. (2010). Asymmetrical demography effects on psychological climate for gender diversity: Differential effects of leader gender and work unit gender composition among Swedish doctors. Human Relations, 63(11), 1661-1685. https://doi.org/10. 1177/0018726710369397

Lampinen, M. S., Suutala, E., \& Konu, A. I. (2017). Sense of community, organizational commitment and quality of services. Leadership in Health Services, 30(4), 378-393. https://doi.org/10.1108/LHS-06-2016-0025

Macionis, J. J. (2009). Sociology (13th edition). New Jersey: Pearson Collage Division.

Maryam, E. W. (2017). Gambaran Sense Of Community Pada Karyawan Bagian Administrasi Di Universitas Muhammadiyah Sidoarjo. Psikologia: Jurnal Psikologi, 2(1), 52-64. https://doi.org/10.21070/psikologia.v2i1.756

McMillan, D. W., \& Chavis, D. M. (1986). Sense of community: A definition and theory. Journal of community psychology, 14(1), 6-23. https://doi.org/10.1002/1520-6629(198601)14: 1 \$ \$6::AID-JCOP2290140103\$\$3.0.CO;2-I
Miner, J. B. (1990). Organizational behavior: Performance and productivity. New York: Random House.

Moeheriono. (2012). Pengukuran kinerja berbasis kompetensi. Jakarta: Raja Grafindo Persada.

Mulyadi. (2007). Sistem perencanaan dan pengendalian manajemen. Jakarta: Salemba Empat.

Nowell, B., \& Boyd, N. M. (2014). Sense of community responsibility in community collaboratives: Advancing a theory of community as resource and responsibility. American Journal of Community Psychology, 54(3-4), 229242. https://doi.org/10.1007/s10464-014-9667-x

Nuqul, F. L. (2004). Hubungan antara religiusitas dengan prasangka. Jurnal Akademika, 2(1), 23-32.

Patria, F. W. (2012). Hubungan antara sense of community dengan distres psikologis pada warga Fakultas Psikologi Universitas Indonesia (Unpublished undergraduate thesis). Universitas Indonesia, Depok.

Peraturan Menteri Pendidikan dan Kebudayaan RI. No. 155/U/1998 Pedoman Umum Organisasi kemahasiswaan di perguruan tinggi. Jakarta: Kementerian Pendidikan dan Kebudayaan.

Prayoga, Y., \& Herdiyanto, Y. K. (2014). Hubungan antara rasa komunitas dengan motivasi kerja pengurus subak. Jurnal Psikologi Udayana, 1(2), 372-380.

Primastika, W. (2019) Tugas perempuan tidak melulu dapur, sumur, dan kasur, pak kapolri. https://tirto.id/tugasperempuan-tidak-melulu-dapur-sumur-dan-kasur-pakkapolri-ekXk (Diakses 10 Februari 2020).

Ramos, A. K., Suarez, M. C., Leon, M., \& Trinidad, N. (2017). Sense of community, participation, and life satisfaction among Hispanic immigrants in rural Nebraska. Kontakt Elsevier, 19(4), e284-e295. https://doi.org/10.1016/j.kontakt. 2017.09.005

Roth, P. L., Purvis, K. L., \& Bobko, P. (2012). A meta-analysis of gender group differences for measures of job performance in field studies. Journal of Management, 38(2), 719-739. https://doi.org/10.1177/0149206310374774

Russell, B. L., \& Trigg, K. Y. (2004). Tolerance of sexual harassment: An examination of gender differences, ambivalent sexism, social dominance, and gender roles. Sex Roles, 50(7), 565-573. https://doi.org/10.1023/B:SERS. 0000023075.32252.fd

Sakall1-Uğurlu, N., Yalçın, Z. S., \& Glick, P. (2007). Ambivalent sexism, belief in a just world, and empathy as predictors of Turkish students' attitudes toward rape victims. Sex Roles, 57(11), 889-895. https://doi.org/10.1007/s11199-007-93132

Sakina, A. I. \& Asiah, D. H. S. (2017). Menyoroti budaya patriarki di Indonesia. Share: Social Work Journal, 7(1), 7180. https://doi.org/10.24198/share.v7i1.13820

Setiawan, R. (2020). Komentator liga 1 cabul dan kurang ajar kepada suporter perempuan. https://tirto.id/komentatorliga-1-cabul-dan-kurang-ajar-kepada-suporter-perempuan$e D 3 K$. (Diakses 20 April 2020) 
Shelton, J. N., Richeson, J. A., Salvatore, J., \& Hill, D. M. (2006). Silence is not golden: The intrapersonal consequences of not confronting prejudice. In Stigma and group inequality (pp. 79-96). Psychology Press.

Sudarmanto. (2009). Kinerja dan pengembangan kompetensi SDM. Yogyakarta: Pustaka Pelajar.

Sukardi. (2004). Metodologi penelitian pendidikan kompetensi dan praktiknya. Jakarta: Bumi Aksara.

Tangkilasan, H. N. (2005). Manajemen publik. Jakarta: Gramedia.

Weber, L., \& Higginbotham, E. (1997). Black and White professional-managerial women's perceptions of racism and sexism in the workplace. In E. Higginbotham \& M. Romero (Eds.), Women and work: A research and policy series, Vol. 6. Women and work: Exploring race, ethnicity, and class (p. 153-175). Sage Publications, Inc.

Weiss, K. G. (2010). Male sexual victimization: Examining men's experiences of rape and sexual assault. Men and Masculinities, 12(3), 275-298. https://doi.org/10.1177/ 1097184X08322632

Wibowo. (2012). Manajemen kinerja. Jakarta: Raja Grafindo Persada.
Wildansyah, S. (2019). Menteri PPPA minta tokoh agama suarakan anti-kekerasan perempuan-anak. https://news.detik.com/berita/d-4770152/menteri-pppaminta-tokoh-agama-suarakan-anti-kekerasan-perempuananak. (Diakses 12 Februari 2020).

Wood, M. E. (2000). Examination of the role of sexism in the overvaluation of female leaders. Dissertation Abstracts International: Section B: The Sciences and Engineering, 60(8-B), 4285.

Yamawaki, N., Darby, R., \& Queiroz, A. (2007). The moderating role of ambivalent sexism: The influence of power status on perception of rape victim and rapist. The Journal of social psychology, 147(1), 41-56. https://doi.org/10.3200/ SOCP.147.1.41-56

Zuhra, W. U. N. (2019). Testimoni kekerasan seksual: 174 penyintas, 79 kampus, 29 kota. https://tirto.id/testimonikekerasan-seksual-174-penyintas-79-kampus-29-kota$d m T W$. (Diakses 12 Februari 2020). 